\title{
IMPACT OF SHORT-TERM ABANDONMENT ON THE STRUCTURE AND FUNCTIONS OF SEMI-NATURAL DRY GRASSLANDS
}

\author{
Domas Uogintas*, Valerijus RašomavičıUS
}

Nature Research Centre, Institute of Botany, Žaliujų Ežerų Str. 49, 12200 Vilnius, Lithuania

*Corresponding author. E-mail: domas.uogintas@gamtc.lt

\begin{abstract}
Uogintas D., Rašomavičius V., 2020: Impact of short-term abandonment on the structure and functions of seminatural dry grasslands. - Botanica, 26(1): 40-48.

A study of the impact of short-term abandonment on the structure and functions of semi-natural dry grasslands in Lithuania was performed. Data on the abundance of vascular plant species, hay and litter samples were collected. At the same time, plant functional traits and Ellenberg indicator values were used to evaluate the effect of abandonment on the structure and functions of semi-natural dry grasslands. The results showed that litter layer was significantly heavier in unmanaged plots compared to that in managed plots. The vascular plant species pool was higher in managed plots, where 62 vascular plant species were identified, while in unmanaged plots 46 species were identified. The species richness was significantly higher in managed semi-natural dry grasslands. Unmanaged plots had $12.3 \pm 0.6$ species, while managed plots had $17.7 \pm 1.2$ species per one square metre. Functional plant traits were similar in mowed and abandoned communities, while functional diversity was lower in unmanaged communities. These results are a clear indicator that the managing of semi-natural dry grasslands creates heterogeneity of the environment.
\end{abstract}

Keywords: functional traits, hemiboreal zone, mowing, plant diversity, plant species richness, semi-natural grasslands.

\section{INTRODUCTION}

The structure and functions of semi-natural dry grasslands is widely influenced by grazing and hay harvesting in forest zones, but socioeconomic and technological changes in Europe have caused many farmers to abandon extensive land use practices (WeHN et al., 2017). It impacts biodiversity and ecosystem services, traditional landscapes and rural communities (BEILIN et al., 2014). Abandonment of grasslands results in an early successional stage with progressive litter accumulation and increasing dominance of few perennial grasses. This is followed by shrub and woody encroachment with obvious changes in the structure and composition of the vegetation (Tilman, 1988). A secondary succession leads to an increase in the height of vegetation, accumulation of litter as well as changes in species composition, which may be found either increasing, stable or decreasing (WANNER et al., 2014). The rate of grassland overgrowth depends on many factors: hydrological regime, availability of woody plant seeds, thickness of litter layer, and disturbances facilitating the establishment of woody plants. At the same moment, very wet and dry grassland communities remain stable as well as mesic grasslands, if there are no disturbances of litter layer, for example, molehills or fires (RŪsIN̦A, 2017).

The litter layer affects communities in various ways: (i) it can reduce the diversity of environmental conditions (light intensity and moisture regime amplitude becomes less diverse), (ii) it can reduce the success of seedling establishment and affects the germination of seeds whose germination needs a higher light requirement for germination (JENSEN \& GuteKunsta, 2003; Rūsiña, 2017); at the same time, 
more competitive species such as Brachypodium pinnatum (L.) P. Beauv., Calamagrostis epigejos (L.) Roth, Dactylis glomerata L. or Elytrigia repens (L.) Nevski suppress lower plant species and reduce plant species diversity (Somodi et al., 2008; Holub et al., 2012; RūsIN̦A, 2017) as well as functional and structural diversity and (iii) it can have an effect of fertilising, because biomass is not removed and the organic content of soil increases.

Semi-natural dry grasslands (Festuco-Brometea erecti communities; habitat type 6210 Semi-natural dry grasslands and scrubland facies on calcareous substrates, Annex I of the EU Habitats Directive) mostly occur in river valleys, especially on slopes and on the upper level of terraces. In Lithuania, there are approximately $27 \mathrm{~km}^{2}$ of the 6210 habitat; the mean size of the habitat patch is 1.6 ha. Seminatural grasslands are the most species-rich habitats for vascular plants in Europe (HAMrE et al., 2010). In addition, the highest recordings of plant species richness across the globe are found in communities of Festuco-Brometea erecti (CHYTRÝ et al., 2015).

Landscapes in Lithuania are the mosaic of forest patches and open vegetation types, mostly agricultural lands. Semi-natural and natural grassland vegetation occurs only in river valleys and on steep hills in moraine upland regions. Traditionally, Festuco-Brometea communities are grazed, because other agricultural activities are difficult due to unsuitable conditions, i.e. small grassland patches, steep slopes, rock outcrops, and inaccessible localities. Only a small part of seminatural dry grasslands, which occurred in mosaic with mesic and alluvial grasslands, were used for hay harvesting. Semi-natural dry grasslands are one of the most threatened habitats in Lithuania, more than $72 \%$ of all these habitats are entirely unmanaged, tree cover average is $2.5 \%$ and shrub cover average is $4.61 \%$. In addition, less than one-third of habitats are without any woody plants (RAŠOMAVIČIUS, 2012).

A significant amount of studies have been carried out in Central and Eastern Europe to investigate various impacts of the abandonment of grasslands as well as the various management methods for conservation of habitats and different taxa (HAMre et al., 2010; Nekrošienè \& SkuOdienĖ, 2012; SAmmul et al., 2012; KLImeŠ et al., 2013; NeuenKAmp et al., 2013). Most studies focus on grazed and abandoned communities, while only a few deals with mowed communi- ties and those communities are usually classified as other types of grassland. That is why we addressed the following question: how does short-term abandonment affect vegetation structure, species richness and functional diversity of mown semi-natural dry grasslands in hemiboreal region?

\section{MATERIALS AND METHODS}

\section{Field study design}

The study sites were selected at three locations on the Šventoji and Širvinta medium river valleys in Lithuania. The field research was carried out in plots established on the upper level of floodplains, which were characterised by fluvial sand soil.

The investigated plots were established in mowed and abandoned patches of semi-natural dry grasslands. At each study site, one part of the grassland is actively being used for harvesting hay once per season; the other part has been abandoned for at least ten years. All other ecological gradients are the same in both parts of each studied area. The boundary between managed and unmanaged parts was used as a profile through the polygon of communities. The profile was divided into five equal segments; each plot was located five metres from the boundary between these two parts. The data were collected in 10 plots of $1 \mathrm{~m}^{2}$ in size: five plots in the managed part and five plots in the abandoned part. The study was carried out in July 2019.

The abundance of each plant species in the plot was evaluated according to the six-grade BraunBlanquet scale, the total cover of plants was measured in percentage scale. The final dataset contained 30 plots and 68 species, the taxonomy of species followed accepted names and synonyms of vascular plants of the European and Mediterranean vascular plant taxa provided by Euro + Med PlantBase (accessed 2019 11).

The aboveground biomass from each plot of $1 \mathrm{~m}^{2}$ was collected. Both live and dead biomass was cut and separated. The biomass of every sample was weighted both in fresh and air-dried using the KERN HDB $5 \mathrm{~K} 5 \mathrm{~N}$ scale.

\section{Plant trait data and analysis}

The effect of abandonment on functions and structure compared to mowing was evaluated using 
five functional plant traits: canopy height, leaf dry matter content, leaf mass, specific leaf area and seed mass. All traits were taken from the LEDA Traitbase (KLEYER et al., 2008). A total of 57 species were fully covered by trait data, for eight species one to three trait data were missing and three species were left uncovered by trait data. For each plot, the community-weighted mean of trait values was calculated according to BRUELHEIDE et al. (2019).

The effect of abandonment on the environment was evaluated using the unweighted mean of Ellenberg indicator values. The values adapted to Central Europe for nutrients, moisture, light, temperature and soil reaction, were used (CHYTRÝ et al., 2018). These data are stored in the Lithuanian vegetation database (EU-LT-001).

\section{Statistical analysis}

Species abundance and frequency, and the Shannon index were analysed using software Juice (TıснÝ, 2002). The litter, fresh grass and hay mass data were analysed and generalized linear model was examined using software PAST (HAMmER et al., 2001). The plant trait community-weighted mean and functional diversity were calculated using software Canoco, version 5 (Ter BraAK \& Šmilauer, 2012). Statistical significance was tested performing the two sample $t$-test and the differences between variances were tested using the $F$-test.

\section{RESULTS AND DISCUSSION}

\section{Grassland productivity}

Overall, there was no statistically significant difference ( $t$-test, $p<0.05$ ) between managed and unmanaged parts according to fresh grass and hay mass.
Managed grassland fresh grass mass was $460.5 \pm$ $45.8 \mathrm{~g} \mathrm{~m}^{-2}$ (mean $\pm \mathrm{SE}$ ), while unmanaged grassland fresh grass mass was $484.3 \pm 66.5 \mathrm{~g} \mathrm{~m}^{-2}$ (Table 1). Managed grassland hay mass was $188.7 \pm 15.1 \mathrm{~g} \mathrm{~m}^{-2}$, while unmanaged grassland hay mass was $197.7 \pm$ $23.4 \mathrm{~g} \mathrm{~m}^{-2}$. Meanwhile, the litter mass was statistically significantly different in unmanaged and managed plots, $172.7 \pm 17.1 \mathrm{~g} \mathrm{~m}^{-2}$ and $87 \pm 10.1 \mathrm{~g} \mathrm{~m}^{-2}$, respectively. The average ratio of dried litter and total above-ground biomass was significantly different in managed and unmanaged plots, $32 \pm 3.9$ and $48 \pm$ $5.2 \%$, respectively.

Litter accumulation varies in different communities. For example, in abandoned fen grassland ecosystems litter mass increases from about $200 \mathrm{~g} \mathrm{~m}^{-2}$ in mid-successional stages to about $600 \mathrm{~g} \mathrm{~m}^{-2}$ in latesuccessional stages (JENSEN \& GUTEKUNSTA, 2003). Over a period of more than 10 years, about $172 \mathrm{~g} \mathrm{~m}^{-2}$ of litter have accumulated in unmanaged semi-natural dry grasslands. In semi-natural grasslands, after seven years of abandonment, litter biomass can reach $70 \%$ of all above ground biomass (RūsIN̦A, 2017). Our study showed that in semi-natural dry grasslands litter biomass reached $48 \%$ of all above-ground biomass during a period longer than 10 years. In contrast, the period of abandonment was too short to obtain statistically significant results in terms of hay mass. Our results show only the trend of hay mass changes in communities, while other authors have found that hay mass increases in abandoned communities (SAMMUL et al., 2012).

\section{Species richness and abundance}

In all investigated plots, the total cover of herb layer was similar, on average $53 \pm 3 \%$ in managed and $45 \pm 5 \%$ in unmanaged plots. The vascular plant

Table 1. Summary of semi-natural dry grassland productivity results in managed (Y) and unmanaged (N) plots

\begin{tabular}{|c|c|c|c|c|}
\hline $\begin{array}{c}\text { Management } \\
\text { type }\end{array}$ & $\begin{array}{l}\text { Mean mass of } \\
\text { fresh grass } \\
\mathrm{g} \mathrm{m}^{-2}\end{array}$ & $\begin{array}{c}\text { Mean mass of } \\
\text { hay } \\
\mathrm{g} \mathrm{m}^{-2}\end{array}$ & $\begin{array}{c}\text { Mean mass of } \\
\text { dried litter } \mathrm{g} \mathrm{m}^{-2}\end{array}$ & Location \\
\hline $\mathrm{Y}$ & 327 & 137 & 130 & $24.88187^{\circ} \mathrm{N}, 55.01096^{\circ} \mathrm{E}$ \\
\hline $\mathrm{N}$ & 215 & 95 & 241 & $24.88187^{\circ} \mathrm{N}, 55.01096^{\circ} \mathrm{E}$ \\
\hline $\mathrm{Y}$ & 429 & 197 & 106 & $25.26823^{\circ} \mathrm{N}, 55.64881^{\circ} \mathrm{E}$ \\
\hline $\mathrm{N}$ & 559 & 232 & 347 & $25.26823^{\circ} \mathrm{N}, 55.64881^{\circ} \mathrm{E}$ \\
\hline Y & 625 & 232 & 64 & $24.4658^{\circ} \mathrm{N}, 55.08588^{\circ} \mathrm{E}$ \\
\hline $\mathrm{N}$ & 679 & 266 & 138 & $24.4658^{\circ} \mathrm{N}, 55.08588^{\circ} \mathrm{E}$ \\
\hline
\end{tabular}


species diversity was higher in managed plots, 62 vascular plant species were identified, while in unmanaged plots, 46 species were identified; in both types of communities 68 species were recognised. Vascular plant species number per plot was significantly higher in managed semi-natural dry grasslands (Fig. 1). Unmanaged plots had $12.3 \pm 0.6$, while managed plots had $17.7 \pm 1.2$ species per plot ( $t$-test, $p<0.05)$. In addition, the Shannon index was significantly greater in managed plots. This confirms not only higher vascular plant species richness, but also the proportion of species abundance as being more equal among communities in managed grasslands.

Vascular plant species diversity was significantly lower in unmanaged plots. A generalized linear model was used to investigate the relation between mass of dried litter and species richness. This model also helps to understand the impact of abandonment on species diversity (Fig. 2). The model shows a clear linear relation between species richness and litter mass in communities. Species richness continuously decreases when litter mass increases. It is the main change in communities after short term abandonment.

Species frequency was different among managed and unmanaged plots. The most frequent species in managed and unmanaged plots are presented in Table 2; diagnostic species of the Festuco-Brometea class are highlighted after MucINA et al. (2016). One-third of all registered species were found only in managed plots. In contrast, $9 \%$ of all species were observed only in unmanaged plots, the most frequent (the frequency in unmanaged plots was more than $10 \%$ ) of these were Thalictrum lucidum and Urtica dioica.

The abundance of species fluctuated from 2 to $38 \%$. It is important to underline several species such as Anthriscus sylvestris, Carex hirta, Elytrigia repens, Filipendula ulmaria, Geranium pratense,
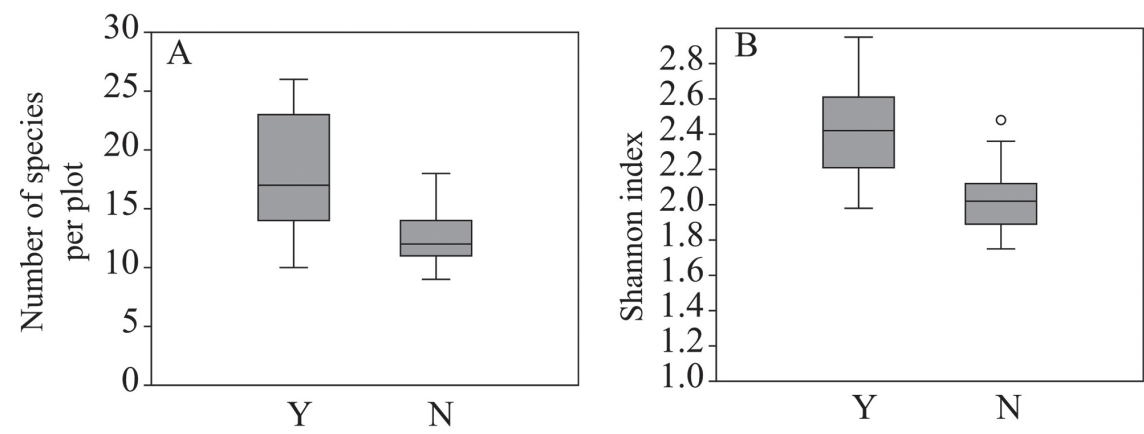

Fig. 1. Number of registered vascular plant species (A) and the Shannon index (B) in managed (Y) and unmanaged (N) plots of Festuco-Brometea communities. The 25-75 percent quartiles are drawn using a box. The median is shown with a horizontal line inside the box. The minimal and maximal values are shown with short horizontal lines and outliers are shown as circles

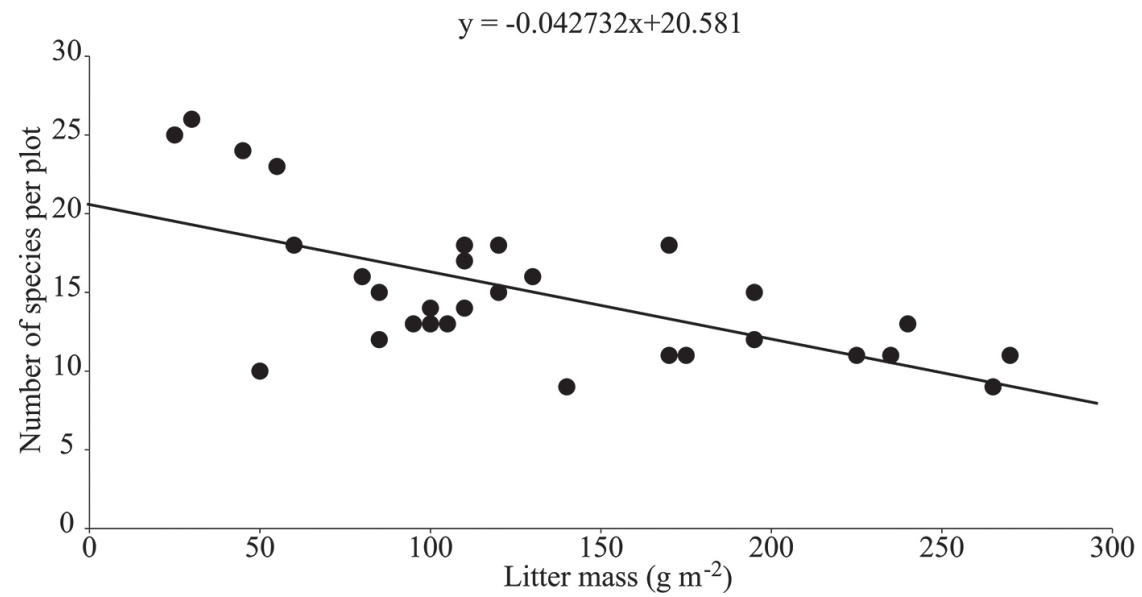

Fig. 2. The impact of litter accumulation on vascular plant species diversity in semi-natural grasslands $(a=-0.04, b=20.6$, $p<0.05)$ 
Table 2. The most frequent ( $>20 \%$ ) plant species in managed $(\mathrm{Y})$ and unmanaged $(\mathrm{N})$ grasslands

\begin{tabular}{|c|c|c|c|c|}
\hline \multirow[t]{2}{*}{ Species } & \multicolumn{2}{|c|}{$\begin{array}{l}\text { Frequency, } \\
\%\end{array}$} & \multicolumn{2}{|c|}{$\begin{array}{c}\text { Median and } \\
\text { (maximum) cover } \\
\text { of species, } \%\end{array}$} \\
\hline & $\mathrm{Y}$ & $\mathrm{N}$ & $\mathrm{Y}$ & $\mathrm{N}$ \\
\hline Festuca rubra L. & 100 & 87 & $13(13)$ & $13(38)$ \\
\hline Dactylis glomerata L. & 93 & 47 & $8(13)$ & $3(13)$ \\
\hline Festuca pratensis Huds. & 87 & 47 & $3(13)$ & $3(13)$ \\
\hline Poa angustifolia $\mathrm{L}$. & 73 & 47 & $13(38)$ & $13(38)$ \\
\hline Equisetum arvense L. & 67 & 60 & $3(38)$ & $3(13)$ \\
\hline Galium album Mill. & 60 & 47 & $13(38)$ & $13(38)$ \\
\hline $\begin{array}{l}\text { Filipendula vulgaris } \\
\text { Moench }\end{array}$ & 60 & 47 & $3(3)$ & $2(13)$ \\
\hline Achillea millefolium L. & 60 & 20 & $3(13)$ & $3(3)$ \\
\hline Geranium pratense L. & 53 & 60 & $3(13)$ & $13(38)$ \\
\hline $\begin{array}{l}\text { Anthryscus sylvestris (L.) } \\
\text { Hoffm. }\end{array}$ & 53 & 53 & $2(13)$ & $3(38)$ \\
\hline $\begin{array}{l}\text { Avenula pubescens (Huds.) } \\
\text { Dumort. }\end{array}$ & 53 & 47 & $13(38)$ & $3(13)$ \\
\hline Galium boreale $\mathrm{L}$. & 53 & 33 & $3(13)$ & $3(13)$ \\
\hline Thalictrum minus L. & 53 & 33 & $3(13)$ & $13(13)$ \\
\hline Vicia cracca L. & 47 & 53 & $2(13)$ & $2(3)$ \\
\hline Heracleum sibiricum L. & 47 & 33 & $2(3)$ & $2(2)$ \\
\hline Knautia arvensis (L.) DC. & 47 & 27 & $2(3)$ & $2(2)$ \\
\hline Veronica chamaedrys L. & 47 & 7 & $2(13)$ & $2(2)$ \\
\hline $\begin{array}{l}\text { Elytrigia repens (L.) } \\
\text { Nevski }\end{array}$ & 40 & 53 & $3(13)$ & $8(38)$ \\
\hline Fragaria viridis Weston & 40 & 27 & $13(38)$ & $25(38)$ \\
\hline $\begin{array}{l}\text { Calamagrostis epigejos } \\
\text { (L.) Roth }\end{array}$ & 33 & 27 & $3(3)$ & $8(13)$ \\
\hline Phleum pratense $\mathrm{L}$. & 33 & 20 & $3(13)$ & $2(2)$ \\
\hline Medicago falcata $\mathrm{L}$. & 27 & 53 & $2(38)$ & $3(13)$ \\
\hline Galium verum $\mathrm{L}$. & 27 & 33 & $8(13)$ & $3(3)$ \\
\hline Potentilla reptans $\mathrm{L}$. & 27 & 27 & $3(13)$ & $8(13)$ \\
\hline Glechoma hederacea L. & 27 & 27 & $2(3)$ & $13(38)$ \\
\hline Carex hirta L. & 13 & 33 & $2(3)$ & $3(13)$ \\
\hline $\begin{array}{l}\text { Rumex thyrsiflorus } \\
\text { Fingerh. }\end{array}$ & 13 & 27 & $2(2)$ & $2(2)$ \\
\hline
\end{tabular}

Diagnostic species of the Festuco-Brometea class are in bold.

Glechoma hederacea and Rumex thyrsiflorus, which indicate eutrophication of communities, show degradation trends of grasslands and are also tall-growing and very competitive species, especially Anthriscus sylvestris, Elytrigia repens and Filipendula ulmaria.
These species were more frequent and/or had higher maximum cover in abandoned communities. For example, Antriscus sylvestris and Filipendula ulmaria had greater median and maximum covers in unmanaged plots, but equal frequency, while cover and frequency of Elytrigia repens were greater in unmanaged plots (Table 2). The similar phenomena of abandoned grassland eutrophication were observed by other authors in Western Europe (RUPPRECHT et al., 2016; Mitchell et al., 2017). Also, Glechoma hederacea indicates a moister environment in abandoned communities, because the evaporation process is slower due to less open soil because of thicker litter layer. In addition, it alerts to lower intensity of light, which means that species are competing for light. In contrast, Avenula pubescens, Dactylis glomerata, Festuca pratensis, Phleum pratense and Poa angustifolia were more frequent and/or had higher cover in managed plots. All these graminoids have adapted to mechanical harm during vegetation season and can, therefore, be more viable in managed communities. Overall, a few dominant species, which had more than $30 \%$ cover in more than $10 \%$ of managed or unmanaged plots, must be mentioned. In managed plots such species were Equisetum arvense and Galium album, while in unmanaged plots dominant species were Elytrigia repens, Festuca rubra, Fragaria viridis and Geranium pratense.

This study demonstrates the impact of short-term abandonment on grasslands species composition after cessation of hay harvesting. The findings of our study reinforce other research reports that underline decreasing of species richness caused by litter layer accumulation and competition for light in the case of cessation grazing in communities (PYKÄLÄ, 2005; WANNER et al., 2014; LeTts et al., 2015; WEHN et al., 2017). It must be mentioned that the similar effects of a decrease of species diversity caused by litter accumulation may cause inappropriate agricultural activities such as long-term mulching (HENSGEN et al., 2016).

\section{Ellenberg indicator values and functional diversi- ty of communities}

Several species indicate changes in community composition due to abandonment. The authors of this paper hypothesize that functional diversity is reduced in unmanaged plots because of a more homogenous 
environment. To understand changes in communities in the early stages of abandonment, we tested mean Ellenberg indicator values, five plant functional traits as well as functional diversity.

The mean Ellenberg soil reaction $(\mathrm{pH})$ and moisture indicator values slightly increased in unmanaged plots compared to those in managed plots. The soil $\mathrm{pH}$ in managed plots was $7.2 \pm 0.08$ and in unmanaged plots it was $7.4 \pm 0.08$. At the same time, the moisture value in managed plots was $4.7 \pm 0.1$ and in unmanaged plots $4.9 \pm 0.1$, but these differences are not statistically significant. Other mean Ellenberg indicator values were similar in all communities - light: $7 \pm 0.02$, temperature: $5.7 \pm 0.06$ and nutrients: $4.7 \pm$ 0.1 . By focusing on the most frequent species, which are found only in managed (22 species) or unmanaged ( 6 species) plots, one can observe a clear trend, i.e. the increase of moisture and nutrient values. For example, on average, moisture values increased from 4 in managed communities to 7 in unmanaged communities, and nutrient averaged values also increased in unmanaged plots from 3.6 to 6 .

Lower Ellenberg indicator values for nutrients and moisture in managed communities show that plants must compete due to lack of minerals and water in the soil, otherwise a thick litter layer can absorb water and keep the soil surface moist. Furthermore, the decomposing of litter acts as a fertilizer in unmanaged communities. It is a reason why establishing nutrient demanding species and semi-natural dry grasslands start shifting into mesic grassland communities (RUPPRECHT et al., 2016; Mitchell et al., 2017).

Several authors have found relations between functional plant traits in managed and unmanaged communities (LouAult et al., 2005; LetTs et al., 2015; WeHN et al., 2017). In this study, there were no statistical differences between managed and unmanaged communities according to plant functional trait values: canopy height $(0.46 \pm 0.02$ and $0.54 \pm$ $0.04 \mathrm{~m}, p=0.102$, respectively), leaf dry matter content $\left(252.2 \pm 3.8\right.$ and $\left.265.3 \pm 5.8 \mathrm{mg} \mathrm{g}^{-1}, p=0.068\right)$, leaf mass $(201.9 \pm 30.6$ and $262.9 \pm 34.8 \mathrm{~g}, p>0.05)$, specific leaf area $\left(20.8 \pm 0.5\right.$ and $21 \pm 0.6 \mathrm{~mm}^{2} \mathrm{mg}^{-1}$, $p>0.05)$ and seed mass $(2.1 \pm 0.2$ and $2.5 \pm 0.3 \mathrm{mg}$, $p>0.05)$. Only differences between variances in canopy height were found $(F=4.735, p<0.05)$.

Canopy height is a consequence of competition for light, only higher plants can occur in unmanaged grasslands compared to managed grasslands. Despite the fact that mean Ellenberg indicator values do not show any changes in light-demanding species composition, plant height is a good competitive vigour for light (CoRNELISSEN et al., 2003), and it varies more in unmanaged plots than in those managed. Varying plant height confirms that light is a strong environmental factor and species start to compete at the first stages of abandonment. Leaf trait values show that species response to abandonment has started. Firstly, specific leaf area and leaf mass indicate that the environment becomes nutrient richer and resource stress is reduced. Secondly, leaf dry matter content indicates a more disturbed environment in managed plots. Increased seed mass in unmanaged plots shows a more complicated establishment of seedlings in abandoned grasslands and the resources stored in seeds tend to help their survival and establishment in litter dense communities. Similar findings were found in long-term grazed and abandoned communities (LetTs et al., 2015; WeHN et al., 2017) at different levels of grazing and mowing, and in fertile grasslands (LouAult et al., 2005).

Although strong differences in terms of functional plant traits were not found, functional diversity is significantly lower in unmanaged communities (Fig. 3).

The results show that environment heterogeneity is decreasing in abandoned communities and it is the

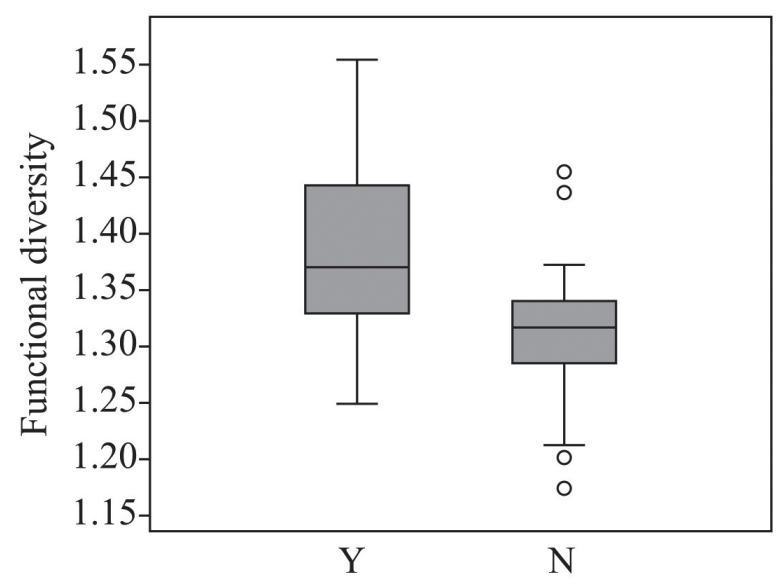

Fig. 3. Functional diversity of managed (Y) and unmanaged (N) communities of semi-natural dry grasslands. The 25-75 percent quartiles are drawn using a box. The median is shown with a horizontal line inside the box. The minimal and maximal values are shown with short horizontal lines and outliers are shown as circles 
main reason for reduced functional diversity. A low range of functional traits indicates an environmental filtering process that causes only a narrow range of functional trait values to be selected (BотTA-DuKÁt \& Czúcz, 2016; WeHn et al., 2017).

In conclusion, this comparative study between mowed and abandoned semi-natural dry grasslands shows that short-term abandonment causes an accumulation of litter layer, which can reach $48 \%$ of the total above-ground biomass. In managed plots, species richness and diversity were higher than in unmanaged plots, and the proportion of species abundance was more equal. This phenomenon was a result of thick litter layer accumulation in abandoned grasslands. After cessation of management, the diversity of nutrients and moisture-demanding species increased in unmanaged plots and those communities started to shift into more mesic ones. A declined functional diversity and the establishment of few dominant species indicate a more homogenous environment in abandoned communities.

\section{REFERENCES}

Beilin R., Lindborg R., Stenseke M., Pereira H.M., Llausàs A., Slätmo E., Cerqueira Y., Navarro L., Rodrigues P., Reichelt N., 2014: Analysing how drivers of agricultural land abandonment affect biodiversity and cultural landscapes using case studies from Scandinavia, Iberia and Oceania. - Land Use Policy, 36: 60-72.

Botta-Dukát Z., Czúcz B., 2016: Testing the ability of functional diversity indices to detect trait convergence and divergence using individual-based simulation. - Methods in Ecology and Evolution, 7: 114-126.

Bruelheide H., Dengler J., Jiménez-Alfaro B. et al., 2019: sPlot - a new tool for global vegetation analyses. - Journal of Vegetation Science, 30(2): 161186.

Chytrý M., Dražil T., Hájek M., Kalníková V., Preislerová Z., Šibík J., Ujházy K., Axmanová I., Bernátová D., Blanár D., Dančák M., Dřevojan P., Fajmon K., Galvánek D., Hájková P., Herben T., HrivnÁK R., JANEČEK Š., JANIŠOVÁ M., JiRÁSKÁ Š., Kliment J., Kochuarová J., Lepš J., Leskovjanská A., Merunková K., Mládek J., Slezák M., Šeffer J., Šefferová V., Škodová I., Uhlírová J.,
Ujházyová M., Vymazalová M., 2015: The most species-rich plant communities in the Czech Republic and Slovakia (with new world records). - Preslia, 87: 217-278.

Chytrý M., Tichý L., Dřevojan P., SÁdlo J., Zelený D., 2018: Ellenberg-type indicator values for the Czech flora. - Preslia, 90: 83-103.

Cornelissen J.H.C., Lavorel S., Garnier E., Díaz S., Buchmann N., Gurvich D.E., Reich P.B., Ter Steege H., Morgan H.D., van Der Heijden M.G.A., Pausas J.G., Poorter H., 2003: A handbook of protocols for standardised and easy measurement of plant functional traits worldwide. - Australian Journal of Botany, 51: 335-380.

European AND MEditerRanean vascular Plant taXa provided by Euro+Med PlantBase. http://ww2. bgbm.org/EuroPlusMed/query.asp accessed [11 2019].

Hammer Ø., Harper D.A.T., Ryan P.D., 2001: PAST: Paleontological statistics software package for education and data analysis. - Palaeontologia Electronica, 4(1): 1-9.

Hamre L.N., Rydgren K., Halvorsen R., 2010: The effects of mulching and abandonment on the viability of the perennial grassland species Plantago lanceolata. - Plant Ecology, 211(1): 147-158.

Hensgen F., Bühle L., Wachendorf M., 2016: The effect of harvest, mulching and low-dose fertilization of liquid digestate on above ground biomass yield and diversity of lower mountain semi-natural grasslands. - Agriculture, Ecosystems and Environment, 216: 283-292.

Holub P., Tưma I., Záhora J., Fiala K., 2012: Different nutrient use strategies of expansive grasses Calamagrostis epigejos and Arrhenatherum elatius. - Biologia, 67(4): 673-680.

Jensen K., Gutekunsta K., 2003: Effects of litter on establishment of grassland plant species: the role of seed size and successional status. - Basic and Applied Ecology, 4: 579-587.

Kleyer M., Bekker R.M., Knevel I.C., Bakker J.P., Thompson K., Sonnenschein M., Poschlod P., Groenendael J.M., van Klimes L., Klimesova J., Klotz S., Rusch G.M., Hermy M., Adriaens D., Boedeltje G., Bossuyt B., Dannemann A., Endels P., Götzenberger L., Hodgson J.G., JaCkel A.K., Kühn L., Kunzmann D., Ozinga W.A., Römermann C., Stadler M., Schlegelmilch J., 
Steendam H.J., Tackenberg O., Wilmann B., Cornelissen J.H.C., Eriksson O., Garnier E., Peco B., 2008: The LEDA Traitbase: a database of life-history traits of Northwest European flora. - Journal of Ecology, 96(6): 1266-1274.

Klimeš L., Hájek M., Mudrák O., Dančák M., PreisLerová Z., HáJKová P. Jongepierová I., Klimešová J., 2013: Effects of changes in management on resistance and resilience in three grassland communities. - Applied Vegetation Science, 16: 640-649.

Letts B., Lamb G.E., Mischiolz M.J., Romo T.J., 2015: Litter accumulation drives grassland plant community composition and functional diversity via leaf traits. - Plant Ecology, 216: 357-370.

Louault F., Pillar V.D., Aufrère J., Garnier E., SousSANA J.-F., 2005: Plant traits and functional types in response to reduced disturbance in a semi-natural grassland. - Journal of Vegetation Science, 16: 151-160.

Mitchell R.J., Hewison R.L., Britton A.J., BrooKer R.W., Cummins R.P., Fielding D.A., Fisher J.M., Gilbert D.J., Hester A.J., Hurskainen S., PakeMAN R.J., PotTs J.M., Riach D., 2017: Forty years of change in Scottish grassland vegetation: Increased richness, decreased diversity and increased dominance. - Biological Conservation, 212(A): 327336.

Mucina L., Bültmann H., Dierssen K., Theurillat J.P., Raus T., Čarni A., Šumberová K., Willner W., Dengler J., García R.G., Chytrý M., Hájek M., Di Pietro R., Iakushenko D., Pallas J., Daniëls F.J., Bergmeier E., Santos Guerra A., Ermakov N., Valachovič M., Schaminée J.H., Lysenko T., Didukh Y.P., Pignatti S., Rodwell J.S., Capelo J., Weber H.E., Solomeshch A., Dimopoulos P., Aguiar C., Hennekens S.M., Tichý L., 2016: Vegetation of Europe: hierarchical floristic classification system of vascular plant, bryophyte, lichen, and algal communities. - Applied Vegetation Science, 19(suppl. 1): 3-264.

Nekrošienè R., Skuodienè R., 2012: Changes in floristic composition of meadow phytocenoses, as landscape stability indicators, in protected areas in Western Lithuania. - Polish Journal of Environmental Studies, 21(3): 703-711.
Neuenkamp L., Metsoja J.A., Zobel M., Hölzel N., 2013: Impact of management on biodiversity-biomass relations in Estonian flooded meadows. - Plant Ecology, 214: 845-856.

PYKÄLÄ J., 2005: Plant species responses to cattle grazing in mesic semi-natural grassland. - Agriculture, Ecosystems and Environment, 108: 109-117.

Rašomavičıus V. (ed.), 2012: EB svarbos natūralių buveinių inventorizavimo vadovas. Gamtos tyrimų centras (in Lithuanian).

Rupprecht D., Gilhaus K., Hölzel N., 2016: Effects of year-round grazing on the vegetation of nutrientpoor grass- and heathlands - evidence from a largescale survey. - Agriculture Ecosystems and Environment, 234: 16-22.

RūsIN̦A S. (ed.), 2017: Protected habitat management guidelines for Latvia, 3. Semi-natural grasslands. Nature Conservation Agency. - Latvia.

Sammul M., Kauer K., KöSter T., 2012: Biomass accumulation during reed encroachment reduces efficiency of restoration of Baltic coastal grasslands. Applied Vegetation Science, 15: 219-230.

Somodi I., Virágh K., Podani J., 2008: The effect of the expansion of the clonal grass Calamagrostis epigejos on the species turnover of a semi-arid grassland. - Applied Vegetation Science, 11: 187-192.

Ter Braak C.J.F., Šmilauer P., 2012: Canoco reference manual and user's guide: software for ordination, version 5.0. Microcomputer Power. - USA.

TICHÝ L., 2002: JUICE, software for vegetation classification. - Journal of Vegetation Science, 13: 451-453.

Tilman D., 1988: Plant strategies and the dynamics and structure of plant communities. - USA.

Wanner A., Suchrow S., Kiehl K., Meyer W., Pohlmann N., Stock M., Jensen K., 2014: Scale matters: impact of management regime on plant species richness and vegetation type diversity in Wadden Sea salt marshes. - Agriculture Ecosystems and Environment, 182: 69-79.

Wehn S., Taugourdeau S., Johansen L., HovsTAD A.K., 2017: Effects of abandonment on plant diversity in semi-natural grasslands along soil and climate gradients. - Journal of Vegetation Science 28: $838-847$. 


\section{TRUMPALAIKIO APLEIDIMO POVEIKIS PUSIAU NATŪRALIŲ ŽOLYNŲ STRUKTŪRAI IR FUNKCIJOMS}

\section{Domas Uogintas, Valerijus RašomaviČIUS}

\section{Santrauka}

Trumpalaikio apleidimo poveikio pusiau natūralių sausųų žolynų (Festuco-Brometea klasės bendrijos) struktūrai ir funkcijoms tyrimai buvo vykdyti dviejų Lietuvos upių slèniuose. Naudojamos (šienaujamos) ir apleistos (nebenaudojamos mažiausiai dešimt metu) bendrijos buvo išsidesšiusios Šventosios ir Širvintos upių aukštesniajame terasų lygmenyje. Apleidimo poveikis bendrijų struktūrai ir funkcijoms buvo nustatytas pagal induočių augalų gausumo ir padengimo vertinimą, šieno ir nuokritų kiekį, augalu funkcines savybes bei Elenbergo indikatorines rūšis.

Tyrimo rezultatai parode, kad nuokritų kiekis buvo reikšmingai didesnis apleistose bendrijų dalyse, lyginant su šienaujamais plotais. Induočių rūšiu ịvairove buvo didesnè naudojamose bendrijose, kuriose identifikuotos 62 augalų rūšys, o nenaudojamose -46 rūšys. Rūšių įsotinimas reikšmingai didesnis naudojamuose žolynuose nei apleistose jo dalyse, atitinkamai $12,3 \pm 0,6$ ir 17,7 $\pm 1,2$ rūšių tyrimų plote. Augalų funkcinès savybès nesiskyrė tiek naudojamose, tiek apleistose bendrijose, tačiau bendra jų funkcinè ịvairovė buvo mažesnè nenaudojamose bendrijose. Tokiu būdu, pusiau natūralių sausujų žolynų naudojimas stimuliuoja jų ịvairovę. 